\title{
Skeletal muscles that actuate sexual displays are specialized for de novo androgen synthesis
}

Eric R. Schuppe ${ }^{1}$, Franz Goller ${ }^{2,3}$, and Matthew J. Fuxjager ${ }^{1,4^{*}}$

${ }^{1}$ Department of Biology, Wake Forest University, 455 Vine Street, Winston-Salem, NC 27101

${ }^{2}$ Department of Biology, University of Utah

${ }^{3}$ Institute for Zoophysiology, University of Münster, Germany

${ }^{4}$ Current address: Department of Ecology and Evolutionary Biology, Brown University,

Providence, RI

*Corresponding Author

Email: matthew_fuxjager@brown.edu

Key words: steroid synthesis, androgens, skeletal muscle, display, sexual selection 


\section{Abstract}

The gonads (testes) act as the primary organ where androgenic hormones are

3 made to regulate reproductive behavior in male vertebrates. Yet many endocrinologists

4 have also long suspected that other tissues in the body can autonomously synthesize their

5 own androgens to support behavioral output. We examine this idea here by studying

6 whether avian skeletal muscles that actuate elaborate socio-sexual displays are

7 specialized to maintain the molecular machinery otherwise needed for de novo androgen

8 synthesis. Our results show that the vocal organ, or syrinx (SYR), of two songbirds

9 species does in fact express all transporters and enzymes necessary to create androgenic

10 hormones from scratch. This includes genes that encode proteins to mediate rate-limiting

11 steps of steroidogenesis, which are seldom found outside of the gonads. We also show

12 that expression levels of these genes are far greater in the SYR than non-display muscles,

13 matching expression levels found in another extra-gonadal site of steroidogenesis - the

14 brain. Furthermore, we uncover a nearly identical gene expression signature in a

15 woodpecker neck muscle, the longus colli ventralis (LC). This tissue actuates the bird's

16 social drum display, which serves the same functions as song. This same study also

17 demonstrates that the elevated expression of steroidogenic genes persists in this neck

18 muscle year-round, suggesting that the LC's capacity to make androgens is a constitutive

19 trait. Altogether, our findings suggest that muscles involved in sexual display is uniquely

20 specialized to locally make steroid hormones, likely supporting their own role in

21 behavioral production. 


\section{INTRODUCTION}

24 Androgenic hormones play a vital role in the regulation of male reproductive

25 behavior, including most forms of courtship and male-male competition [1].

26 Conventional wisdom says that the gonads (testes) mediate these effects, given that they

27 synthesize androgenic steroids de novo and release them into circulation [2, 3]. Yet, the

28 dependency of reproductive behavior on the gonads may be more complex than this

29 model suggests. Many species, for example, express androgen-dependent behavioral

30 traits at times when the testes are fully regressed and incapable of producing steroids [4-

31 8]. Such results imply that androgen synthesis may occur in other tissues throughout the

32 vertebrate body, locally fueling steroidal modulation of behavioral output. Although this

33 idea provides an intriguing way to conceptualize how behavior can be adaptively

34 decoupled from testicular functioning [9, 10], our understanding of where extra-gonadal

35 androgen synthesis occurs and how it is specialized to support sexual traits remains

36 largely unclear.

37 Here we explore these topics by assessing mechanisms of de novo androgen

38 synthesis in skeletal muscles that support elaborate socio-sexual behavior. Skeletal

39 muscle is a major androgen target in the vertebrate body [11-13], and prior work shows

40 that androgenic regulation of muscle is often necessary for reproduction [14-16].

41 Courtship is a prime example: muscles that mediate displays used to attract mates are

42 often enriched with androgen receptor $[13,17,18]$, and blocking androgenic activation of

43 these receptors disrupts the effectiveness or recognizability of signaling behavior [14-16].

44 Importantly, however, we know that individuals can often produce these same displays

45 when their gonads are not making steroids $[4,5,19]$. Tissues other than the testes may 
46 therefore act as the source of androgens to regulate how muscle governs behavioral

47 outflow. One potential site of androgen synthesis is the display muscle itself-that is,

48 myocytes may make their own androgens to locally influence their ability to control

49 behavior. Yet we know little about the capacity of skeletal muscles to create its own

50 androgens, making this hypothesis difficult to assess.

51 One of the best ways to examine whether a given tissue can make its own steroid

52 hormones de novo is to measure how it expresses the transporters and enzymes that make

53 up the steroid biosynthesis pathway [Figure 1; 20, 21, 22]. Indeed, there are only a few

54 tissues other than the gonads that readily express these genes-namely, skin, heart, and

55 brain [22-24]. Most other tissues in vertebrates lack key transporters and enzymes that

56 mediate steroid biosynthesis, particularly the rate-limiting step of this process where

57 cholesterol is brought into the mitochondria and converted to the steroid hormone

58 precursor, pregnanolone [25-27]. Accordingly, if selection drives the evolution of de

59 novo androgen synthesis in displays muscles, then these tissues should express the rate-

60 limiting transporters and enzymes that facilitate this important first steroid of

61 steroidogenesis as well as the remaining enzymes that metabolize pregnanolone into

62 testosterone. Moreover, if muscles are specialized to do this, then we also expect that

63 they express the genes more abundantly than muscles not involved in display production.

64 In fact, such expression should be on par with other extra-gonadal sites of de novo steroid

65 synthesis, like the brain $[22,28]$.

66 We test these predictions in three different bird species: white-breasted nuthatches

67 (Sitta carolinensis), zebra finches (Taeniopygia guttata), and downy woodpeckers

68 (Dryobates pubescens). The first reason that these taxa are ideal to study muscular 
69 androgen synthesis is that they each produce an elaborate socio-sexual display that

70 depends on androgen-muscle interactions. Nuthatches and zebra finches, for example,

71 court mates and compete with rivals by singing $[29,30]$. This behavior is controlled by a

72 vocal organ called the syrinx (SYR), which is composed of several muscles that sit on the

73 tracheo-bronchial junction [31]. Neural activation of this musculature shapes the spectral

74 features of song [32], and studies show that androgenic hormones fine tune this process

75 by acting directly on androgen receptors in SYR muscle $[11,15]$. On the other hand,

76 downy woodpeckers signal to conspecifics during territorial contests by drumming their

77 bill on trees at speeds averaging 16 beats/sec [33]. Such behavior is mediated by a neck

78 muscle called the longus colli ventralis (LC) [34], and recent work shows that androgens

79 likely act on it to help support the performance of drumming behavior [35]. The second

80 reason why these three species are ideal for the proposed work is that they all are known

81 to produce their respective displays when circulating androgens levels are basal,

82 including periods of non-breeding $[5,30,36]$. We therefore test whether the SYR and LC

83 muscles of these birds not only express the necessary machinery for de novo androgen

84 synthesis, but also whether these tissues are specialized for such endocrine functionality.

\section{RESULTS}

87 Muscular expression of steroid biosynthesis enzymes

88 We first tested whether display muscles express the necessary transporters and 89 enzymes for de novo androgen synthesis. Using reverse transcription PCR, we assayed

90 the presence of transcripts for these proteins in both the white-breasted nuthatch SYR and

91 downy woodpecker LC. Our data showed that all these transcripts were present in both 
92 display muscles, although some were expressed at very low levels (Figure S1). We also

93 included testes in these PCR reactions as a positive control, verifying our primers and

94 their efficacy in the PCR reactions. Overall, our data indicate that all transporters and

95 enzymes needed to turn cholesterol into an androgenic ligand (see Figure 1) are present in

96 both the nuthatch SYR and the woodpecker LC.

97

98 Specializations in the capacity for de novo androgen synthesis in the syrinx

Next, we explored whether the machinery for de novo androgen synthesis is specialized in display muscle. To do this, we used real-time quantitative PCR (qPCR) to compare relative expression of androgen biosynthesis genes among the (i) gonad (testis), 102 which are the main site of androgen synthesis; (ii) brain, which is a known site of extra103 gonadal androgen synthesis; (iii) SYR and/or LC display muscles, and (iv) pectoralis 104 muscle (PEC), a large non-display muscle that powers locomotion in these species.

106 tissues in the expression of nearly all androgen biosynthesis genes (Figure VI-3A and B;

107 Table VI-1). The one exception was zebra finch TPSO, which was highly expressed in 108 every tissue. Post-hoc analyses of these main effects showed that gonads have the highest 109 expression of each gene. At the same time, our findings also highlighted that SYR muscle 110 expresses these genes at similar levels to the brain, another extragonadal site of de novo 111 steroid synthesis [22]. Gene expression levels in SYR muscle were also significantly 112 greater than in a non-display muscle, the PEC (Figure VI-3A and B; Table VI-1). Only 113 cytochrome p450 17 (cyp17, or steroid 17 $\alpha$-monooxygenase) showed an expression 114 profile in SYR that was lower than in the brain and equal to the PEC. Cyp17 converts 
115 progestins to androgens [37], its abundance is unlikely to limit the tissue's capacity for 116 androgen synthesis.

117 Perhaps the most important result of this analysis is that expression patterning 118 described above applies to both steroidogenic acute regulatory protein (StAR) and 119 cytochrome p450 family 11 (cyp11a1, or side chain cleavage enzyme). These gene 120 products mediate the rate-limiting steps of steroidogenesis-StAR transports cholesterol

121 from the outer mitochondrial membrane to the inner membrane [38], while side chain

122 cleavage enzymatically converts cholesterol to pregnanolone [37]. Most extra-gonadal

123 tissues fail to express either of these genes, rendering them incapable of de novo steroid 124 synthesis [25-27]. Thus, display muscle is unique in this regard, as it expresses relatively 125 high levels of these genes to likely initiate the process of steroidogenesis.

126 One of the marked species differences in the SYR is that the nuthatch expresses 127 aromatase, while the zebra finch does not (Figure 2A and B; Table 1). Aromatase 128 converts the androgen testosterone to estradiol, meaning that these species likely differ in 129 the amount of estrogens that the SYR can make. To date, most work suggests that 130 estrogens play little role in the regulation of the SYR; yet, these results suggest that this 131 may not be the case for all birds. Notably, both the nuthatch and zebra finch SYR express $1325 \alpha$-reductase, which converts testosterone to a more potent androgenic ligand 133 (dihydrotestosterone). 


\section{Steroid biosynthesis in the woodpecker neck muscle}

In a second experiment, we explored the expression profile of these same androgen biosynthesis genes in the downy woodpecker neck muscle, the LC [39]. This tissue actuates the birds drum display, which is functionally similar to birdsong but produced through hammering the bill against a tree (and not via the SYR). We find that LC muscle expresses all transporters and enzymes necessary for androgen biosynthesis, including the transcripts for both StAR and side chain cleavage (Figure 2C; Table 1). Moreover, each gene is more abundantly expressed in the LC than in the PEC (nondisplay muscle). The one exception to this pattern is cyp17, whose expression levels are indistinguishable between the two muscles (Figure 2C; Table 1). Importantly, this difference between the LC and PEC may be associated specifically with drumming in woodpeckers, as no such difference in gene expression profile was present between these two muscles in the nuthatch.

Meanwhile, in the downy woodpecker, transcript levels are typically lower in the LC and PEC, compared to both the brain and gonad. Expression of StAR is not consistent with this trend, since its expression is similar between LC and brain. Nonetheless, our data collectively point to the woodpecker LC as a muscle that maintains a specialized capacity for de novo androgen synthesis.

\section{Constitutive vs. plastic regulation of enzyme expression}

In a final analysis, we investigated whether muscular expression of androgen biosynthesis enzymes are linked to muscle use per se [40]. We therefore compared expression of these genes in the woodpecker LC between the breeding season and non- 
157 breeding season. Downy woodpeckers drum far more frequently during the breeding

158 season, although they do produce occasional drums in the non-breeding season [36].

159 Thus, if expression of steroid biosynthesis enzymes were associated with display related

160 muscle use, we would expect a strong seasonality in their expression level. Our data did 161 not support this hypothesis, in that expression levels of all androgen biosynthesis genes 162 were indistinguishable between the breeding and non-breeding seasons. We even 163 confirmed that this assay for seasonal variation in gene expression was robust by 164 comparing gonads from these same birds (Figure 3; Table 2). Indeed, when the testes of 165 these individuals produce testosterone in the spring, all androgen biosynthesis genes are 166 more abundantly expressed than during the winter when the gonads are regressed. These 167 data are therefore consistent with a model in which muscle "activity" does not guide the 168 expression of the steroid biosynthesis machinery in the myocyte.

\section{DISCUSSION}

Androgenic steroids can act via skeletal muscle to mediate many elaborate social

172 displays that animals use for courtship and competition [29, 30, 33]. Our current study

173 uncovers an important new dimension to this process by showing that select muscles that

174 govern such behavior are likely specialized for de novo androgen synthesis. This means

175 that the muscle can make its own androgenic hormones, and thus allow steroidal

176 regulation to occur outside the confines of the hypothalamic-pituitary-gonadal (HPG)

177 axis. We provide several lines of evidence to support this idea. First, two different display

178 muscles - the songbird SYR and the woodpecker LC-express all the transporters and 179 enzymes necessary to convert cholesterol into bioactive androgens. This includes the 
180 expression of the genes that encode StAR and side-chain cleavage, which underlie the

181 rate-limiting steps of steroid biosynthesis [37] and are typically absent in extra-gonadal

182 tissue [25-27]. Second, expression levels of these genes are relatively greater in display

183 muscles compared to a non-display muscle, and they even match levels in the brain (a

184 known sites of steroid synthesis outside of the gonads). Lastly, the abundance of

185 transcripts for genes involved in steroidogenesis are stable in display muscle across the

186 year. This stands in contrast to the gonads, where transcript levels drop during the non-

187 breeding seasons when circulating androgens are not made. Thus, the capacity of display

188 muscle to make its own androgens is likely a constitutive property of the tissue itself,

189 failing to change in response to fluctuations in circulating testosterone or behavior-related

190 muscle activity [35].

\section{Functional significance}

To our knowledge, our study is the first to indicate that skeletal muscle maintains

194 the molecular machinery necessary for de novo androgen synthesis. Moreover, this study

195 is also the first to suggest that this capacity is specialized specifically in muscles that 196 actuate elaborate sexual displays. Thus, given the importance of androgen-muscle 197 interactions to these behaviors, we hypothesize that myocytic synthesis of androgenic 198 steroids supports fine motor control of movements that underlie effective communication.

199 There are several ways in which these effects might occur. For example, androgens might 200 act via the SYR to increase its muscle mass [11], enhance its capacity for neuromuscular 201 transmission [41, 42], modulate its fiber type composition [43, 44], and/or calcium 202 cycling machinery [45]. Such changes boost force production and the speed of muscle 
203 contraction, and thus facilitate rapid temporal features of song [44, 46]. Several of these

204 acoustic parameters - including the on- and offset of vocalizations, rapid modulation of

205 sound frequency and amplitude, as well as the rapid switching between contributions of

206 the two sound generators-likely play a critical role in how a male's singing ability is

207 assessed by same- and opposite-sex conspecifics [47-49]. At the same time, it is possible

208 that androgenic modulation of the rapid movement of the sound producing labia into the

209 airstream lowers the required pressure for sound onset, which in turn leads to louder

210 vocalizations [50] that enhance the potency of song [51, 52]. Past work certainly supports

211 this view, showing that androgenic regulation of the SYR mediates several important

212 acoustic elements of song, but not the motivation to produce it. For example, if androgen

213 action in the SYR of canaries (Serinus canaria) is selectively blocked, then males

214 produce songs with a disrupted syllable morphology and substantially reduced

215 performance of 'special trills' [15]. This latter component to the display stimulates

216 female copulation solicitation displays more than any other [53], suggesting that

217 androgen-SYR interactions are vital to a male's ability to copulate.

218 Many of these same principles also likely apply to the woodpecker LC. This

219 muscle helps actuate the swift hammering behavior of the drum display [34, 54], meaning

220 that the tissue must repeatedly contract and relax at an especially rapid rate [up to $20 \mathrm{~Hz}$;

221 33]. Recent work shows that the LC is in fact specialized for this role, expressing high

222 levels of genes that encode proteins to mediate quick calcium buffering and reuptake

223 [55]. This should result in rapid muscle relaxation, which in turn increases contraction-

224 relaxation cycling speeds. One way to maintain such machinery is through androgenic

225 action, which regulates genes linked to calcium cycling in the myocyte [56, 57]. The 
226 woodpecker LC is likely no exception, given that it is heavily enriched with androgen

227 receptor [35]. Thus, local synthesis of androgens in this muscle probably supports its

228 ability to generate a fast drum, which is more effective during territorial combat [33].

229 Precedent for this idea comes from experimental work in a species of tropical bird, called

230 the golden-collared manakin (Manacus vitellinus). In this species, androgens act on the

231 wing musculature to dramatically increase the speed at which males perform acrobatic

232 courtship displays $[14,58]$. Females preferentially mate with faster displaying males,

233 meaning that sexual selection for rapid display behavior likely drives the evolution of

234 androgenic regulation of the wing muscles [59].

235 In light of our hypotheses about the function of de novo androgen synthesis in

236 display muscle, we must also point out that these tissues express steroidogenic gene

237 transcripts at levels roughly $1-5 \%$ of those in the gonads. These levels may at first seem

238 low; however, we find that they are similar to those found in the brain, which is a known

239 site of steroid synthesis [22, 60, 61]. Moreover, evidence suggests that cardiomyocytes

240 express similarly low levels of steroidogenic enzymes relative to the testes [62], yet the

241 cells are still fully capable of producing functional steroids de novo [24, 63]. It is

242 therefore likely that display muscle-despite expressing low levels of the genes involved

243 in steroidogenesis - can produce fully functional androgens.

\section{Evolutionary Significance}

246 Why might display musculature evolve the capacity to synthesize androgens in

247 the first place? One reason might be that it helps individuals temporally liberate their

248 display behavior from functional barriers set by the hypothalamic-pituitary-gonadal axis. 
249 Most seasonally breeding individuals increase levels of circulating androgens at the onset

250 of the reproductive season, particularly when males compete for resources and/or mates

251 [64]. Thus, if this was the primary source of androgens to mediate display behavior by

252 way of the muscle, then individuals could only display during these times of the year. Yet

253 it is well established that several species readily perform socio-sexual signals outside of

254 this narrow context -indeed, this ability is often adaptive [7, 8, 19, 65]. This is no

255 exception for the species we examine herein, as all three sing or drum when circulating

256 levels of androgens are otherwise basal [5, 30, 36]. Thus, the ability of the SYR and LC

257 to make their own androgens likely allows individuals of each species to maintain the

258 peripheral components of their display motor systems year-round. In this way, they

259 would be capable of producing effective signals regardless of androgen levels in the

260 blood, as long as the brain could still initiate such behavior (see below).

261 Androgen synthesis in display muscle may also help mitigate fitness 'costs'

262 normally associated with these hormones. Indeed, gonadal androgens suppress immune

263 function, diminish fat reserves, and slow the process of wound healing [66-68].

264 Prolonged exposure to circulating androgens outside periods of territoriality and/or

265 breeding also interferes with parental care [69]. All these effects negatively impact

266 viability and reproductive success [70, 71], and thus selection favors mechanisms that

267 reduce or offset their impact. As such, low-levels of androgenic synthesis in the target

268 muscles likely provides a solution to this 'evolutionary problem' by allowing the

269 performance of the androgen-dependent behavior without high levels of circulating

270 androgens [72]. 
272

273

274 involved in complex animal behavior, a view currently gaining acceptance [73].

275 However, these findings should not detract from the long-held view that circulating

276 androgens are critical to the organization and activation of many sexual behaviors. Both

277 of these models likely apply to most vertebrates, and it is the integration of these two

278 viewpoints that forwards our thinking about how steroid systems accommodate

279 reproductive traits. Accordingly, we hypothesize that circulating brain-level androgen

280 action helps regulate facets of reproductive behavior related to sensory integration,

281 arousal, motivation, and/or attention [74]. By contrast, we expect that androgens act

282 through muscle to mediate performance-related aspects of behavior, such as agility,

283 speed, endurance, etc. [75]. In this way, both "top down" and "bottom up" channels of

284 steroid action are necessary to fully actuate certain behavioral traits. Our current findings

285 therefore suggest that such channels are not necessarily coupled to the same hormonal

286 source (i.e., HPG axis), rendering the hormonal mechanisms far more labile-both

287 mechanistically and evolutionarily — than previously thought.

289 Conclusions

290 Here, we find that important display muscles in three different avian species 291 maintain the machinery needed to undergo de novo androgen synthesis. This trait appears 292 to be a constitutive specialization of the muscle itself, resembling a similar specialization 293 of the brain for the ability to produce its own steroid. We hypothesize that androgen 294 synthesis in display muscle is essential for maintaining its ability to actuate necessary 
295 signaling behavior outside of the breeding season, and thus is an adaptation to enhance

296 social communication behavior.

\section{METHODS}

299 Animals

300 All appropriate federal, state, and university authorities approved of the methods

301 described below. During March and April, we passively captured male downy 302 woodpeckers $(n=4)$ and white-breasted nuthatches $(n=3)$ using mist nets in the woodlands 303 of Forsyth County, North Carolina (USA). Individuals were immediately euthanized via 304 cervical dislocation to keep the LC muscle intact and flash frozen on dry ice. We stored 305 specimens at $-80^{\circ} \mathrm{C}$ until they were later processed, at which point we dissected out the 306 whole brain, gonads, SYR muscle (nuthatches only), LC muscle, and PEC muscle. 307 During these dissections, we also verified that the gonads from each individual were 308 enlarged to a size consistent with an actively breeding bird. During November to 309 December of the same year, we passively captured and dissected a set of non-breeding 310 down woodpeckers $(n=3)$ using the same techniques described above. We similarly 311 verified that the testes were regressed to a size consistent with a non-breeding bird.

312 Finally, we euthanized adult (age $>120$ days) male zebra finches $(\mathrm{n}=5)$ with an 313 overdose of isoflurane before dissection. The birds had been individually housed in a $31431.8 \mathrm{~cm} \times 22.9 \mathrm{~cm} \times 27.9 \mathrm{~cm}$ wire cages with newspaper lining. They were fed a mixture 315 of red and white millet, canary seed, and water ad libitum, and they were supplemented 316 with peas and corn every other day. 


\section{RNA extraction and reverse transcription}

We homogenized each tissue sample in TRIzol Reagent ${ }^{\mathrm{TM}}$ using a rotor/stator homogenizer set to medium speed. We extracted total RNA from these samples with a Zymo Direct-zol RNA miniprep kit (Zymo Research, Irvine, CA), in which we included an initial phenol-chloroform separation of RNA as per manufacturer instructions. Next, we treated RNA samples with DNAse and reverse transcribed $1 \mu \mathrm{g}$ of RNA, using SuperScript IV Reverse Transcriptase (Invitrogen). Each reaction occurred for $10 \mathrm{~min}$ at $55^{\circ} \mathrm{C}$, followed by $10 \mathrm{~min}$ at $80^{\circ} \mathrm{C}$.

\section{PCR and Sequencing}

Using cDNA from the extracted tissues, we amplified the different genes that encode the proteins that mediate steroid biosynthesis (Figure S1). The primers for the initial PCR reactions were designed from either the downy woodpecker or the zebra finch genomes to conserved regions of each gene (Table S1). All PCR reactions contained 40 ng of cDNA, $0.5 \mu \mathrm{M}$ of forward primer, $0.5 \mu \mathrm{M}$ of reverse primer, OneTaq 2x Mastermix (New England Biology). Reactions were run at $96{ }^{\circ} \mathrm{C}$ for $5 \mathrm{~min}$, followed by 40 cycles of $96^{\circ} \mathrm{C}$ for $30 \mathrm{~s} ; 57-60^{\circ} \mathrm{C}$ for $30 \mathrm{~s}$; and $68^{\circ} \mathrm{C}$ for $30 \mathrm{~s}$. Each reaction was completed with a final extension step at $68^{\circ} \mathrm{C}$ for $5 \mathrm{~min}$.

Resulting PCR products were imaged on a $1 \%$ agarose gel to verify that fragments matched their expected size. We then purified the PCR products using a GeneJet PCR purification kit (ThermoFisher) and had them sequenced (Eton Bioscience). For cyp11a1, STAR, and 17BHSD, resulting purified PCR products were amplified a second time using the parameters described above to generate a high enough 
341 concentration of DNA for accurate and efficient sequencing. All PCR products matched

342 the expected gene of interest.

\section{Quantitative PCR ( $q P C R)$}

345 We used quantitative real-time PCR (qPCR) to measure each steroidogenic 346 enzyme's gene expression in the different tissues of our three species relative to GAPDH 347 (housekeeping control). In all three species, we confirmed that GAPDH was acting as an 348 appropriate endogenous control by verifying that there were no significant differences in 349 between tissues in GAPDH expression (all $\mathrm{p}$ values $>0.2$ ). For this analysis, reactions 350 were run in an Applied Biosystems QuantStudio3 machine. We used the gene sequences 351 obtained from our PCR runs to generate species-specific primers (Table S2), and we ran 352 each reaction with $100 \mathrm{ng}$ of cDNA, $0.9 \mathrm{mM}$ of each primer, and SYBR Green Master 353 Mix (Applied Biosystems). For all genes, we included negative controls that consisted of 354 all elements in the reactions described above except cDNA. Reactions were run using the 355 following parameters: $50{ }^{\circ} \mathrm{C}$ for $2 \mathrm{~min}, 95^{\circ} \mathrm{C}$ for $10 \mathrm{~min}$, followed by 40 cycles of $95{ }^{\circ} \mathrm{C}$ 356 for $15 \mathrm{~s}$, and $60{ }^{\circ} \mathrm{C}$ for $1 \mathrm{~min}$. We added a final dissociation stage to the end of the 357 reaction process, which consisted of $95{ }^{\circ} \mathrm{C}$ for $15 \mathrm{~s}, 60{ }^{\circ} \mathrm{C}$ for $30 \mathrm{~s}$, and finally $95{ }^{\circ} \mathrm{C}$ for $35815 \mathrm{~s}$. All negative controls were undetectable.

359 All measurable samples were detectable with CT values below 35. However, in a 360 handful of cases, mRNA for a given gene interest was not detectable after 40 cycles (see 361 Table S3d)—we therefore list count these tissues as not expression the gene of interest 362 [i.e., 'not detectable' (n.d.); See Figure 3]. Reaction efficiencies were between 90\% and $363110 \%$, and we used the standard curve method to measure relative expression (i.e., 
364 quantity of gene of interest /quantity GAPDH). The standard curves used in all the

365 current experiments were generated serially diluted (1:4) pooled cDNA.

367 Data analysis

368 To next investigate whether there are tissue differences in mRNA expression of 369 each of the steroidogenic enzymes, we performed linear mixed models (LMM) for each 370 species with tissue as a fixed factor. To account for the non-independence of gene 371 expression levels between tissues in the same animal, we used individual identity as a 372 random factor in each model. In all analyses, significant main effects were further 373 examined with post-hoc comparisons, using FDR corrections to account for multiple

374 contrasts. We used independent t-tests to determine how the capacity for steroid synthesis

375 changed in the testis, LC muscle, and PEC muscle across seasons in downy woodpeckers.

376 Furthermore, we performed FDR corrections to account for the number of LMMs and t-

377 tests performed. All analyses were performed in R (v3.3.2).

379 Data accessibility. The data will be uploaded to Dryad upon acceptance of the 380 manuscript.

381 Ethics. All the experiments in this study were conducted with approval from the Wake 382 Forest University Institution Animal Care and Use Committee (\# A16-187).

383 Author contributions. ERS participated in study design, collected the animals, 384 performed lab experiments, analyzed data, and wrote the manuscript. FG and MJF 385 participated in study design, analyzed data, and wrote the manuscript.

386 Competing interests. The authors have no competing interests to report. 
bioRxiv preprint doi: https://doi.org/10.1101/740720; this version posted August 20,2019 . The copyright holder for this preprint (which was not certified by peer review) is the author/funder. All rights reserved. No reuse allowed without permission.

387 Acknowledgements. We thank Johnny Petersen, Emma Vivlamore, and Ryan Walsh for 388 field and laboratory assistance.

389 Funding. This work was funded by National Science Grant (IOS-1655730) to M.J.F. 


\section{REFERENCES}

1. Adkins-Regan E. 2005 Hormones and animal social behavior, Princeton University Press.

2. Phoenix C.H., Goy R.W., Young W.C. 1967 Sexual behavior: General aspects. Neuroendocrinology 2, 163-196.

3. Blaustein J.D., Olster D.H. 1989 Gonadal steroid hormone receptors and social behaviors. In Molecular and cellular basis of aocial behavior in vertebrates (pp. 31-104, Springer.

4. Schlinger B.A., Barske J., Day L., Fusani L., Fuxjager M.J. 2013 Hormones and the neuromuscular control of courtship in the golden-collared manakin (Manacus vitellinus). Front Neuroendocrinol 34(3), 143-156.

5. Dunn A.M., Zann R.A. 1996 Undirected song in wild zebra finch flocks: contexts and effects of mate removal. Ethology 102(4), 529-539.

6. Moore M.C., Marler C.A. 1987 Effects of testosterone manipulations on nonbreeding season territorial aggression in free-living male lizards, Sceloporus jarrovi. Gen Comp Endocrinol 65(2), 225-232.

7. Hau M., Stoddard S.T., Soma K.K. 2004 Territorial aggression and hormones during the non-breeding season in a tropical bird. Horm Behav 45(1), 40-49.

8. Hau M., Wikelski M., Soma K.K., Wingfield J.C. 2000 Testosterone and yearround territorial aggression in a tropical bird. Gen Comp Endocrinol 117(1), 20-33. 9. $\quad$ Soma K.K., Scotti M.-A.L., Newman A.E.M., Charlier T.D., Demas G.E. 2008 Novel mechanisms for neuroendocrine regulation of aggression. Front Neuroendocrinol 29(4), 476-489.

10. Saldanha C.J., Remage-Healey L., Schlinger B.A. 2011 Synaptocrine signaling: steroid synthesis and action at the synapse. Endocr Rev 32(4), 532-549.

11. Veney S.L., Wade J. 2004 Steroid receptors in the adult zebra finch syrinx: a sex difference in androgen receptor mRNA, minimal expression of estrogen receptor $\alpha$ and aromatase. Gen Comp Endocrinol 136(2), 192-199.

12. Feng N.Y., Katz A., Day L.B., Barske J., Schlinger B.A. 2010 Limb muscles are androgen targets in an acrobatic tropical bird. Endocrinology 151(3), 1042-1049.

13. Mangiamele L.A., Fuxjager M.J., Schuppe E.R., Taylor R.S., Hödl W., Preininger D. 2016 Increased androgenic sensitivity in the hind limb muscular system marks the evolution of a derived gestural display. Proc Natl Acad Sci U S A 113(20), 5664-5669. 14. Fuxjager M.J., Longpre K.M., Chew J.G., Fusani L., Schlinger B.A. 2013 Peripheral androgen receptors sustain the acrobatics and fine motor skill of elaborate male courtship. Endocrinology 154(9), 3168-3177.

15. Alward B.A., Madison F.N., Gravley W.T., Ball G.F. 2016 Antagonism of syringeal androgen receptors reduces the quality of female-preferred male song in canaries. Anim Behav 119, 201-212.

16. Yong L., Thet Z., Zhu Y. 2017 Genetic editing of the androgen receptor contributes to impaired male courtship behavior in zebrafish. J Exp Biol 220(17), 30173021 .

17. Johnson M.A., Kircher B.K., Castro D.J. 2018 The evolution of androgen receptor expression and behavior in Anolis lizard forelimb muscles. Journal of Comparative Physiology A 204(1), 71-79. 
18. Fuxjager M.J., Eaton J., Lindsay W.R., Salwiczek L.H., Rensel M.A., Barske J., Sorenson L., Day L.B., Schlinger B.A. 2015 Evolutionary patterns of adaptive acrobatics and physical performance predict expression profiles of androgen receptor-but not oestrogen receptor-in the forelimb musculature. Funct Ecol 29(9), 1197-1208.

19. Jenssen T.A., Greenberg N., Hovde K.A. 1995 Behavioral profile of free-ranging male lizards, Anolis carolinensis, across breeding and post-breeding seasons. Herpetol Monogr, 41-62.

20. Taves M.D., Plumb A.W., Sandkam B.A., Ma C., Van Der Gugten J.G., Holmes D.T., Close D.A., Abraham N., Soma K.K. 2014 Steroid profiling reveals widespread local regulation of glucocorticoid levels during mouse development. Endocrinology 156(2), 511-522.

21. Tobiansky D.J., Korol A.M., Ma C., Hamden J.E., Jalabert C., Tomm R.J., Soma K.K. 2017 Testosterone and corticosterone in the mesocorticolimbic system of male rats: effects of gonadectomy and caloric restriction. Endocrinology 159(1), 450-464.

22. London S.E., Monks D.A., Wade J., Schlinger B.A. 2006 Widespread capacity for steroid synthesis in the avian brain and song system. Endocrinology 147(12), 5975-5987.

23. Cirillo N., Prime S.S. 2011 Keratinocytes synthesize and activate cortisol. Journal of cellular biochemistry 112(6), 1499-1505.

24. Takeda Y., Miyamori I., Yoneda T., Iki K., Hatakeyama H., Blair I.A., Hsieh

F.Y., Takeda R. 1994 Synthesis of corticosterone in the vascular wall. Endocrinology 135(5), 2283-2286.

25. Endo D., Kanaho Y.-I., Park M.K. 2008 Expression of sex steroid hormonerelated genes in the embryo of the leopard gecko. Gen Comp Endocrinol 155(1), 70-78. 26. Kusakabe M., Zuccarelli M.D., Nakamura I., Young G. 2009 Steroidogenic acute regulatory protein in white sturgeon (Acipenser transmontanus): cDNA cloning, sites of expression and transcript abundance in corticosteroidogenic tissue after an acute stressor. Gen Comp Endocrinol 162(2), 233-240.

27. Goetz F.W., Norberg B., McCauley L.A.R., Iliev D.B. 2004 Characterization of the cod (Gadus morhua) steroidogenic acute regulatory protein (StAR) sheds light on StAR gene structure in fish. Comparative Biochemistry and Physiology Part B: Biochemistry and Molecular Biology 137(3), 351-362.

28. Kimoto T., Ishii H., Higo S., Hojo Y., Kawato S. 2010 Semicomprehensive analysis of the postnatal age-related changes in the mRNA expression of sex steroidogenic enzymes and sex steroid receptors in the male rat hippocampus. Endocrinology 151(12), 5795-5806.

29. Nowicki S., Searcy W.A. 2004 Song function and the evolution of female preferences: why birds sing, why brains matter. Ann N Y Acad Sci 1016(1), 704-723. 30. Kilham L. 1972 Reproductive behavior of white-breasted nuthatches II. Courtship. The Auk 89(1), 115-129.

31. Goller F., Cooper B.G. 2004 Peripheral motor dynamics of song production in the zebra finch. Ann N Y Acad Sci 1016(1), 130-152.

32. Vicario D.S., Nottebohm F. 1988 Organization of the zebra finch song control system: I. Representation of syringeal muscles in the hypoglossal nucleus. J Comp Neurol 271(3), 346-354.

33. Schuppe E.R., Fuxjager M.J. 2018 High - speed displays encoding motor skill trigger elevated territorial aggression in downy woodpeckers. Funct Ecol 32(2), 450-460. 
34. Kaiser M. 1990 Untersuchungen zur Biomechanik des Balztrommelns der Specte (Picidae). Beitr Vogelkd 36, 129-159.

35. Schuppe E.R., Fuxjager M.J. In revision Phenotypic variation reveals sites of evolutionary constraint in the androgenic signaling pathway. Horm Behav.

36. Kilham L. 1962 Reproductive behavior of downy woodpeckers. The condor 64(2), 126-133.

37. Hanukoglu I. 1992 Steroidogenic enzymes: structure, function, and role in regulation of steroid hormone biosynthesis. The Journal of steroid biochemistry and molecular biology 43(8), 779-804.

38. Kallen C.B., Billheimer J.T., Summers S.A., Stayrook S.E., Lewis M., Strauss

J.F. 1998 Steroidogenic acute regulatory protein (StAR) is a sterol transfer protein. J Biol Chem 273(41), 26285-26288.

39. van der Leeuw A.H.J., Bout R.G., Zweers G.A. 2001 Control of the craniocervical system during feeding in birds. Am Zool 41(6), 1352-1363.

40. Aizawa K., Iemitsu M., Otsuki T., Maeda S., Miyauchi T., Mesaki N. 2008 Sex differences in steroidogenesis in skeletal muscle following a single bout of exercise in rats. J Appl Physiol.

41. Luine V., Nottebohm F., Harding C., McEwen B.S. 1980 Androgen affects cholinergic enzymes in syringeal motor neurons and muscle. Brain Res 192(1), 89-107. 42. Bleisch W., Luine V.N., Nottebohm F. 1984 Modification of synapses in androgen-sensitive muscle. I. Hormonal regulation of acetylcholine receptor number in the songbird syrinx. J Neurosci 4(3), 786-792.

43. Holmes M.M., Bartrem C.L., Wade J. 2007 Androgen dependent seasonal changes in muscle fiber type in the dewlap neuromuscular system of green anoles. Physiol Behav 91(5), 601-608.

44. Uchida A.M., Meyers R.A., Cooper B.G., Goller F. 2010 Fibre architecture and song activation rates of syringeal muscles are not lateralized in the European starling. $J$ Exp Biol 213(7), 1069-1078.

45. Fuxjager M.J., Barske J., Du S., Day L.B., Schlinger B.A. 2012 Androgens regulate gene expression in avian skeletal muscles. PLoS One 7(12), e51482.

46. Elemans C.P.H., Mead A.F., Rome L.C., Goller F. 2008 Superfast vocal muscles control song production in songbirds. PLoS One 3(7), e2581.

47. Vallet E., Kreutzer M. 1995 Female canaries are sexually responsive to special song phrases. Anim Behav 49(6), 1603-1610.

48. Vallet E., Beme I., Kreutzer M. 1998 Two-note syllables in canary songs elicit high levels of sexual display. Anim Behav 55(2), 291-297.

49. Leitner S., Voigt C., Metzdorf R., Catchpole C.K. 2005 Immediate early gene (ZENK, Arc) expression in the auditory forebrain of female canaries varies in response to male song quality. J Neurobiol 64(3), 275-284.

50. Mencio C., Kuberan B., Goller F. 2016 Contributions of rapid neuromuscular transmission to the fine control of acoustic parameters of birdsong. J Neurophysiol 117(2), 637-645.

51. Forstmeier W., Kempenaers B., Meyer A., Leisler B. 2002 A novel song parameter correlates with extra-pair paternity and reflects male longevity. Proc $R$ Soc Lond B Biol Sci 269(1499), 1479-1485. 
52. Ritschard M., Riebel K., Brumm H. 2010 Female zebra finches prefer highamplitude song. Anim Behav 79(4), 877-883.

53. Drăgănoiu T.I., Nagle L., Kreutzer M. 2002 Directional female preference for an exaggerated male trait in canary (Serinusanaria) song. Proc R Soc Lond B Biol Sci 269(1509), 2525-2531.

54. Jenni L. 1981 Das skelettmuskelsystem des halses von buntspecht und mittelspecht Dendrocopos major undmedius. J Ornithol 122(1), 37-63.

55. Schuppe E.R., Petersen J.O., Fuxjager M.J. 2018 Woodpecker drumming behavior is linked to the elevated expression of genes that encode calcium handling proteins in the neck musculature. J Exp Biol 221(15), jeb180190.

56. Rome L.C., Cook C., Syme D.A., Connaughton M.A., Ashley-Ross M., Klimov A., Tikunov B., Goldman Y.E. 1999 Trading force for speed: why superfast crossbridge kinetics leads to superlow forces. Proceedings of the National Academy of Sciences 96(10), 5826-5831.

57. Rome L.C., Syme D.A., Hollingworth S., Lindstedt S.L., Baylor S.M. 1996 The whistle and the rattle: the design of sound producing muscles. Proceedings of the National Academy of Sciences 93(15), 8095-8100.

58. Fuxjager M.J., Miles M.C., Goller F., Petersen J., Yancey J. 2017 Androgens support male acrobatic courtship behavior by enhancing muscle speed and easing the severity of its tradeoff with force. Endocrinology 158(11), 4038-4046.

59. Fusani L., Day L.B., Canoine V., Reinemann D., Hernandez E., Schlinger B.A. 2007 Androgen and the elaborate courtship behavior of a tropical lekking bird. Hormones and behavior 51(1), 62-68.

60. Sakamoto H., Ukena K., Tsutsui K. 2002 Dendritic spine formation in response to progesterone synthesized de novo in the developing Purkinje cell in rats. Neurosci Lett 322(2), 111-115.

61. Taves M.D., Gomez-Sanchez C.E., Soma K.K. 2011 Extra-adrenal glucocorticoids and mineralocorticoids: evidence for local synthesis, regulation, and function. American Journal of Physiology-Endocrinology and Metabolism 301(1), E11E24.

62. Kayes-Wandover K.M., White P.C. 2000 Steroidogenic enzyme gene expression in the human heart. The Journal of Clinical Endocrinology \& Metabolism 85(7), 25192525 .

63. Young M.J., Clyne C.D., Cole T.J., Funder J.W. 2001 Cardiac steroidogenesis in the normal and failing heart. The Journal of Clinical Endocrinology \& Metabolism 86(11), 5121-5126.

64. Goymann W., Landys M.M., Wingfield J.C. 2007 Distinguishing seasonal androgen responses from male-male androgen responsiveness-revisiting the challenge hypothesis. Horm Behav 51(4), 463-476.

65. Wingfield J.C., Soma K.K. 2002 Spring and autumn territoriality in song sparrows: same behavior, different mechanisms? Integr Comp Biol 42(1), 11-20. 66. Mills S.C., Hazard L., Lancaster L., Mappes T., Miles D., Oksanen T.A., Sinervo B. 2008 Gonadotropin hormone modulation of testosterone, immune function, performance, and behavioral trade-offs among male morphs of the lizard Uta stansburiana. The American Naturalist 171(3), 339-357. 
571 67. Ketterson E.D., Nolan Jr V., Wolf L., Ziegenfus C., Dufty Jr A.M., Ball G.F., 572 Johnsen T.S. 1991 Testosterone and avian life histories: the effect of experimentally 573 elevated testosterone on corticosterone and body mass in dark-eyed juncos. Horm Behav 574 25(4), 489-503.

575 68. Ashcroft G.S., Mills S.J. 2002 Androgen receptor-mediated inhibition of 576 cutaneous wound healing. The Journal of clinical investigation 110(5), 615-624.

577 69. De Jong B., Lens L., Amininasab S.M., van Oers K., Darras V.M., Eens M., 578 Pinxten R., Komdeur J., Groothuis T.G.G. 2016 Effects of experimentally sustained 579 elevated testosterone on incubation behaviour and reproductive success in female great 580 tits (Parus major). Gen Comp Endocrinol 230, 38-47.

581 70. Marler C.A., Moore M.C. 1988 Evolutionary costs of aggression revealed by 582 testosterone manipulations in free-living male lizards. Behav Ecol Sociobiol 23(1), 21-26. 583 71. Martínez-Padilla J., Pérez-Rodríguez L., Mougeot F., Ludwig S.C., Redpath S.M. 5842014 Experimentally elevated levels of testosterone at independence reduce fitness in a 585 territorial bird. Ecology 95(4), 1033-1044.

586 72. Wingfield J.C., Lynn S.E., Soma K.K. 2001 Avoiding the 'costs' of testosterone: 587 ecological bases of hormone-behavior interactions. Brain Behav Evol 57(5), 239-251.

588 73. Schlinger B.A., Paul K., Monks D.A. 2018 Muscle, a conduit to brain for 589 hormonal control of behavior. Horm Behav 105, 58-65.

590 74. Alexander G.M., Sherwin B.B. 1991 The association between testosterone, sexual 591 arousal, and selective attention for erotic stimuli in men. Horm Behav 25(3), 367-381.

592 75. Fuxjager M.J., Lee J.-H., Chan T.-M., Bahn J.H., Chew J.G., Xiao X., Schlinger

593 B.A. 2016 Research resource: hormones, genes, and athleticism: effect of androgens on 594 the avian muscular transcriptome. Mol Endocrinol 30(2), 254-271.

595 76. Caraguel C.G.B., Stryhn H., Gagné N., Dohoo I.R., Hammell K.L. 2011 Selection 596 of a cutoff value for real-time polymerase chain reaction results to fit a diagnostic

597 purpose: analytical and epidemiologic approaches. $J$ Vet Diagn Invest 23(1), 2-15. 


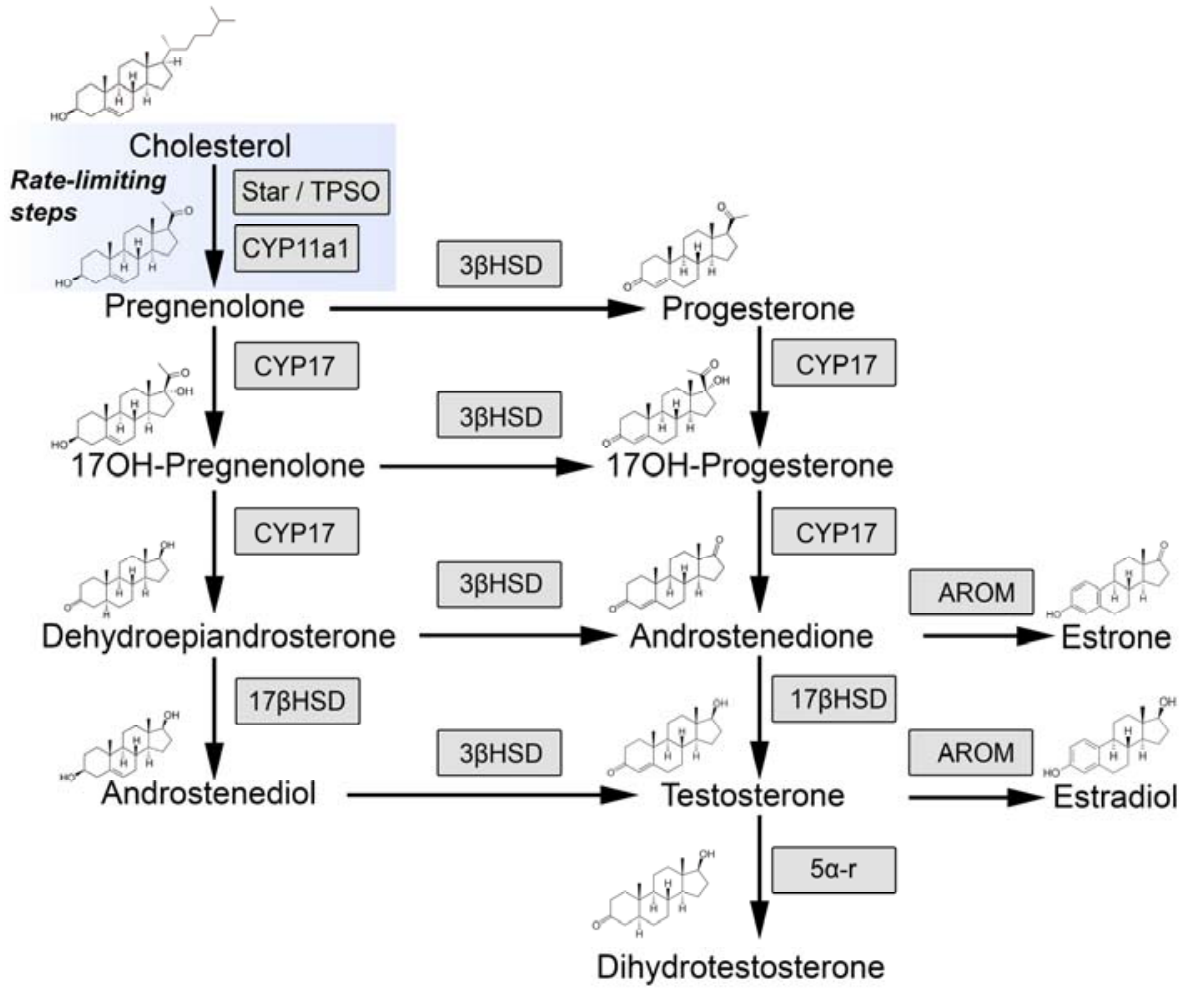

600 Figure 1. Pathway that outlines the multi-step conversion of cholesterol to androgenic (red box)

601 and estrogenic (green box) hormones. The rate limiting proteins in de novo steroid synthesis (blue

602 box) play an important role in the initial transport (steroidogenic acute regulator protein [StAR]

603 and translocator protein [TPSO]) and the subsequent enzymatic conversion (cyp11a1) of

604 cholesterol to pregnenolone. Other enzymes responsible for the conversion of this hormone to

605 other steroid metabolites, including androgens (17 $\beta$-hydroxysteroid dehydrogenase [17BHSD]

606 and 3-oxo-5 $\alpha$-steroid 4-dehydrogenases [5 $\alpha-r]$ ) and estrogens (Aromatase [AROM]). The latter

607 (AROM) is also important because it act through intracellular estrogen receptor, which are not

608 specialized in muscles that participate in sexual signaling [18]. All enzymes are highlighted in

609 grey rectangles. 
A.

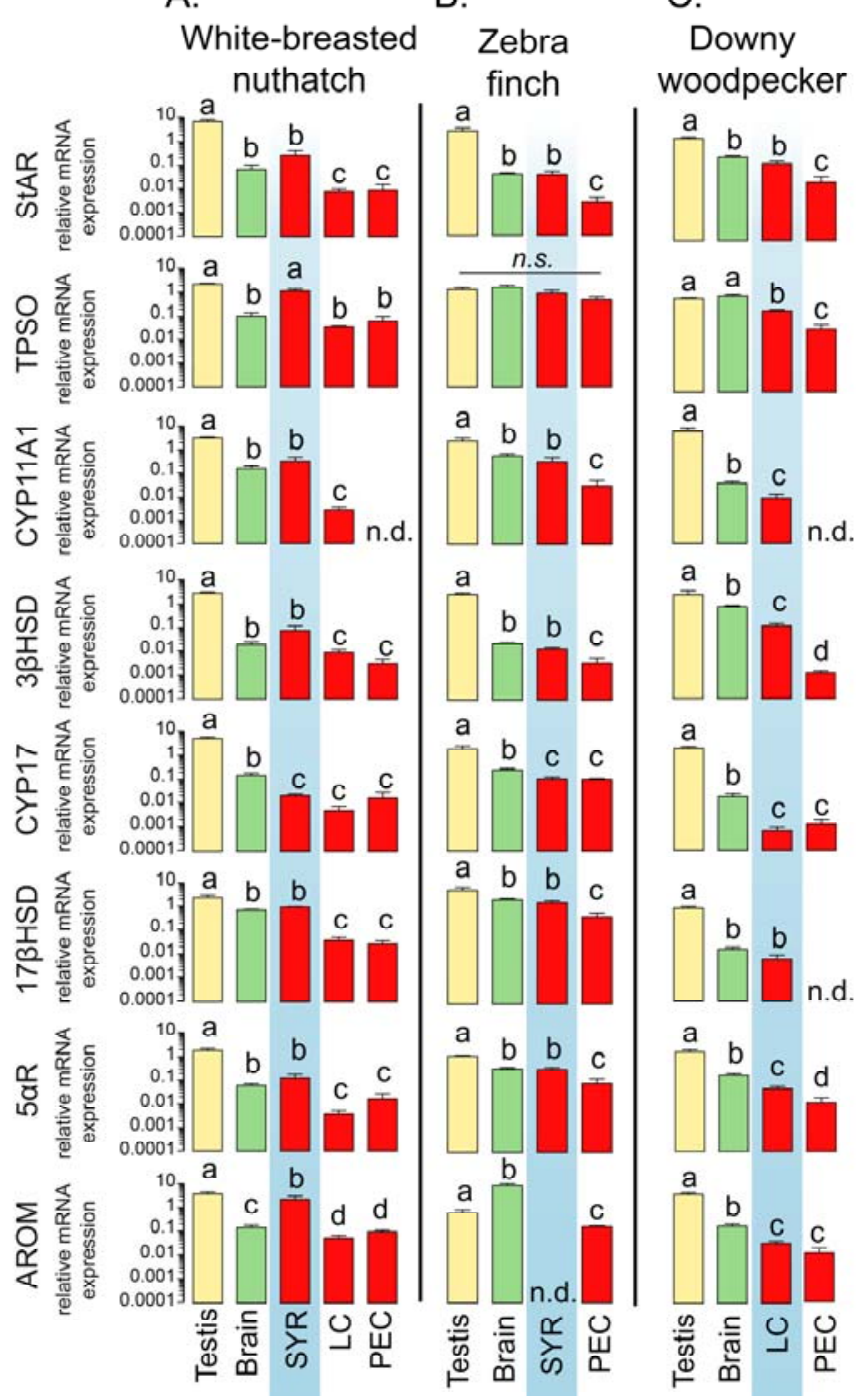

C. woodpecker
610

611

612

613

614

615

616

617

618

619

620

Display muscle .

.

.

列

(1) 


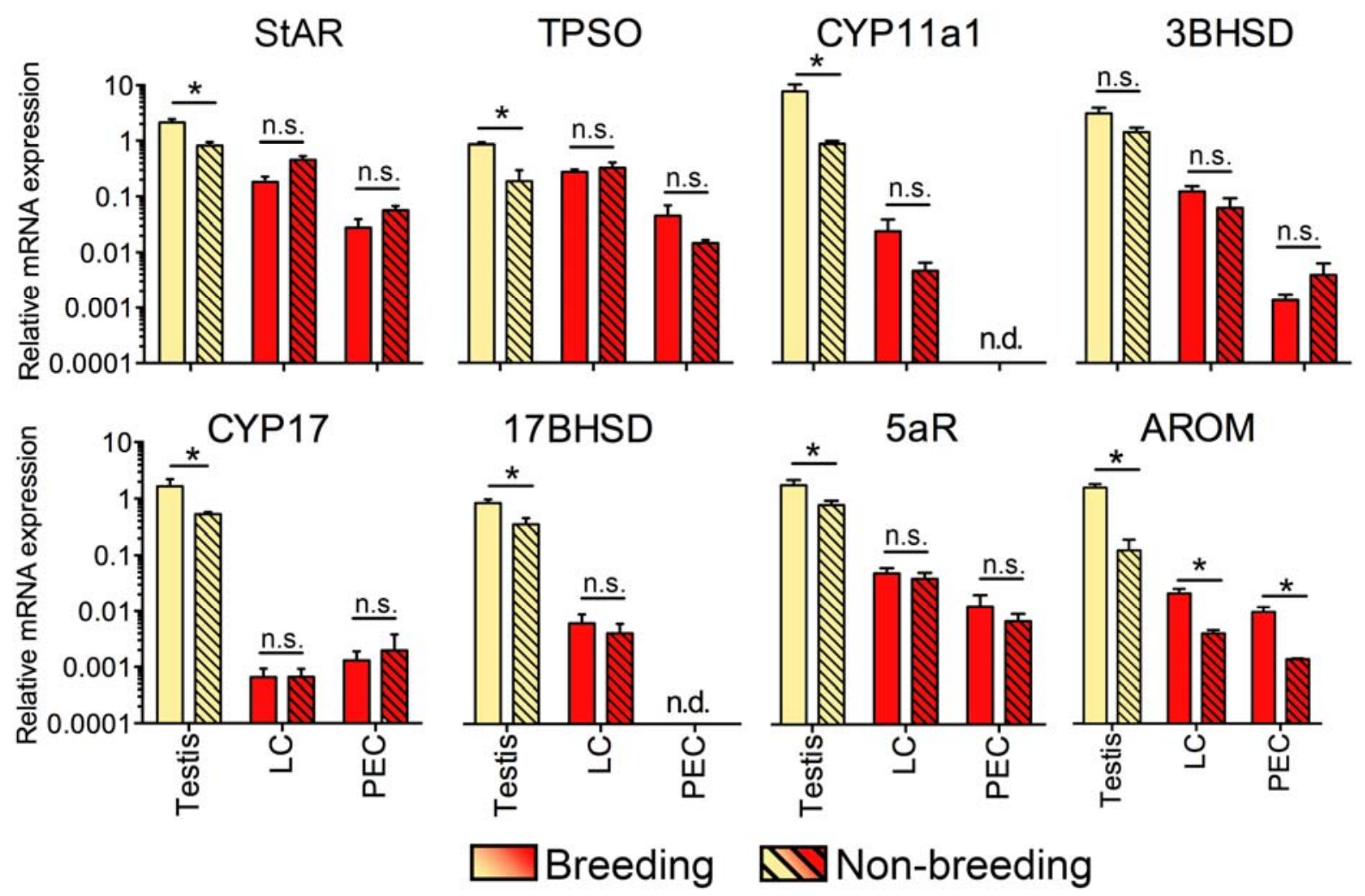

621

622

623

624

625

626

Figure 3. Expression of steroidogenic enzymes in the testis, longus colli ventralis (LC),

23 and pectoralis (PEC) of breeding (solid bars) and non-breeding (hashed bars) male

24 downy woodpeckers. Bars represent mean \pm SEM. Asterisks denote significant

25 differences $(\mathrm{p}<0.05)$ between the breeding and non-breeding season. n.s. denotes

26 comparisons that did not significantly differ from each other. 
627 Table 1 Summary of linear mixed models used to assess tissue differences in steroidogenic enzyme expression in male zebra finches, white-

628 breasted nuthatches, and downy woodpeckers

\begin{tabular}{|c|c|c|c|c|c|c|c|c|}
\hline & STAR & TPSO & Cyp11a1 & 3BHSD & Cyp17 & 17BHSD & 5aR & AROM \\
\hline Zebra finch & $\begin{array}{l}F_{3,10}=62.40, \\
p<0.001\end{array}$ & $\begin{array}{l}\mathrm{F}_{3,10}=3.32 \\
\mathrm{p}=0.07\end{array}$ & $\begin{array}{l}F_{3,10}=8.64 \\
p<0.01\end{array}$ & $\begin{array}{l}\mathrm{F}_{3,10}=74.84 \\
\mathrm{p}<0.001\end{array}$ & $\begin{array}{l}\mathrm{F}_{3,10}=31.18, \\
\mathrm{p}<0.001\end{array}$ & $\begin{array}{l}\mathrm{F}_{3,10}=8.34 \\
\mathrm{p}<0.01\end{array}$ & $\begin{array}{l}\mathrm{F}_{3,10}=17.14, \\
\mathrm{p}<0.001\end{array}$ & $\begin{array}{l}F_{3,10}=59.85, \\
p<0.001\end{array}$ \\
\hline $\begin{array}{l}\text { White- } \\
\text { breasted } \\
\text { nuthatch }\end{array}$ & $\begin{array}{l}\mathrm{F}_{4,12}=22.64, \\
\mathrm{p}<0.001\end{array}$ & $\begin{array}{l}\mathrm{F}_{4,10}=26.79 \\
\mathrm{p}<0.001\end{array}$ & $\begin{array}{l}\mathrm{F}_{4,11}=27.07 \\
\mathrm{p}<0.001\end{array}$ & $\begin{array}{l}\mathrm{F}_{4,11}=48.23 \\
\mathrm{p}<0.001\end{array}$ & $\begin{array}{l}\mathrm{F}_{4,11}=21.03, \\
\mathrm{p}<0.001\end{array}$ & $\begin{array}{l}\mathrm{F}_{4,11}=68.12 \\
\mathrm{p}<0.001\end{array}$ & $\begin{array}{l}F_{4,12}=26.30 \\
p<0.001\end{array}$ & $\begin{array}{l}\mathrm{F}_{4,12}=33.04, \\
\mathrm{p}<0.001\end{array}$ \\
\hline $\begin{array}{l}\text { Downy } \\
\text { woodpecker }\end{array}$ & $\begin{array}{l}F_{3,10}=33.62, \\
p<0.001\end{array}$ & $\begin{array}{l}F_{3,7.13}=27.89, \\
p<0.001\end{array}$ & $\begin{array}{l}F_{3,10}=7.33 \\
p<0.01\end{array}$ & $\begin{array}{l}\mathrm{F}_{3,7.57}=217.71 \\
\mathrm{p}<0.001\end{array}$ & $\begin{array}{l}\mathrm{F}_{3,10}=58.01, \\
\mathrm{p}<0.001\end{array}$ & $\begin{array}{l}\mathrm{F}_{3,7}=80.77 \\
\mathrm{p}<0.001\end{array}$ & $\begin{array}{l}\mathrm{F}_{3,7.88}=104.66, \\
\mathrm{p}<0.001\end{array}$ & $\begin{array}{l}F_{3,10}=22.38, \\
p<0.001\end{array}$ \\
\hline
\end{tabular}


downy woodpeckers across seasons

STAR TPSO Cyp11a1 3BHSD

\section{Testis}

$$
\begin{array}{r}
\text { STAR } \\
(5)=4.29
\end{array}
$$

$\mathrm{t}(5)=3.30$,

$\mathrm{p}<0.01 *$

$\mathrm{p}=0.04^{*}$

Cyp11a1

3BHSD

Cyp17
$\mathrm{t}(5)=7.27$,

$\mathrm{t}(5)=6.28$
$\mathrm{p}<0.01^{*}$

$\mathrm{t}(5)=2.16$

$\mathrm{p}<0.01 *$

$\mathrm{t}(5)=5.84$

$\mathrm{p}<0.01 *$

$\mathrm{t}(5)=2.86$,

$\mathrm{p}=0.05$

$\mathrm{t}(5)=6.29$

$\mathrm{p}<0.01$

LC

$$
t(7)=-2.39
$$

$\mathrm{t}(7)=$

$\mathrm{t}(7)=1.28, \mathrm{p}=\mathrm{t}(7)=1.61, \mathrm{p}=$

$\mathrm{t}(7)=$

$\mathrm{p}=0.07$

$-0.48, \mathrm{p}$

0.25
5

0.17

$-0.28, p=0.79$

$\mathrm{t}(7)=0.83$,

$\mathrm{t}(7)=0.55$,

$\mathrm{t}(7)=5.53$,

$\mathrm{p}=0.44$

$\mathrm{p}=0.61$

$\mathrm{p}<0.01 *$

PEC

$$
\begin{array}{ll}
\mathrm{t}(7)= & \mathrm{t}(7)=1.22 \\
-1.80, \mathrm{p}=0.13 & \mathrm{p}=0.27
\end{array}
$$

n.d.

$\begin{array}{ll}\mathrm{t}(7)= & \mathrm{t}(7)=0.52 \\ -1.32, \mathrm{p}=.24 & \mathrm{p}=0.63\end{array}$

n.d.

$t(7)=-0.45$,

$\mathrm{p}=0.67$

$\mathrm{t}(7)=3.78$,

$\mathrm{p}<0.01 *$

$635 *$ denote significant differences after FDR correction for multiple tests

636 n.d. denotes transcripts that were not detectable in a particular tissue 